\title{
El ensayo en el norte grande de Chile. Autores Y TEMAS. LA REFLEXIÓN EN LA FRONTERA HISTORIA/ NATURALEZA: 1950-1970*
}

\author{
José Antonio González Pizarro **
}

\begin{abstract}
Resumen
Se examina la singularidad del ensayo nortino en un contexto de crisis económica y social del norte grande y de cuestionamiento del filosofar en el país. Los autores nortinos meditaron en torno de la primacía de la naturaleza del desierto en su región, conjugando que en esa naturaleza se encuentra la clave de la adversidad a la habitabilidad humana y contradictoriamente en ese espacio se ha desenvuelto el relato que ha fundamentado el proceso histórico de la épica salitrera y la viabilidad de los asentamientos modernos. El uso del ensayo posibilitó acopiar otros géneros en su fundamento interpretativo y, además, plantear las diferencias entre los creadores.
\end{abstract}

Palabras clave: Ensayo, Chile, Norte, Historia, Naturaleza.

\section{The Essay in the BIG North of Chile. Authors AND Topics. Reflection On the History / NATURe Border: 1950-1970}

\begin{abstract}
The singularity of the northern essay, in the context of the economic and social crisis of the big north and of questioning philosophical thinking in the country, is analyzed. Northern authors will meditate on the priority of the regional desert nature, concluding that the key of adversity to human habitability is found in this nature and that this is the space where the account underlying the historical process of the nitrate epics and viability of modern settlements have contradictorily taken place. Essays made it possible to gather other genders in their interpretation basis and also pose the differences among creators.
\end{abstract}

Keywords: Essay, Chile, North, History, Nature.

Recibido: 06-10-2012

Aceptado: 08-09-2014

\footnotetext{
* $\quad$ Este trabajo se enmarca en la ejecución del proyecto Fondecyt 1095130 y de la Iniciativa Científica Núcleo Milenio "Ciencia Regional y Políticas Públicas" de la Facultad de Economía de la Universidad Católica del Norte, año 2012.

** Doctor en Historia, Universidad Católica del Norte, Antofagasta, Chile. jagonzal@ucn.cl
} 


\section{Aproximaciones al ensayo nacional y la reflexión regional}

Hablar de la producción ensayística del norte grande en las décadas de 1950 y 1960, conlleva a plantearse algunos asuntos respecto de la legitimidad del género y su significado en nuestro medio cultural. Una primera cuestión apunta si el pensar en nuestro país es homogéneo en sus preocupaciones y cuestiones tratadas, desde una perspectiva geográfica. Y un segundo tema se refiere a los factores o condicionantes coadyuvantes que requiere el reflexionar en nuestra larga geografía, esto principalmente por la dicotomía entre los espacios urbanos -metrópoli y ciudades medianas- y los rurales.

En cuanto a la primera situación se tiene el testimonio del filósofo ítalo-alemán Ernesto Grassi, de fines de la década de 1950, quien después de ejercer la docencia en Chile, puso en tela de juicio al ambiente nacional como espacio para reflexionar. Comparando la vida existente en Europa, motivadora para filosofar, Santiago de Chile se mostraba como:

Un mundo ahistórico... Afuera todo amenaza disolver lo que tenemos en nosotros; la realidad de la naturaleza es de una violencia que no se puede imaginar: las montañas, las distancias, las soledades... cuando aún los perros se ponen a ladrar con la experiencia atávica del peligro, cuando los gallos se ponen a cantar en la noche mientras del cielo pende una luna como un faro espectral, sólo entonces se puede comprender lo que en Europa hace siglos se ha olvidado: qué cosas significa en la naturaleza proyectar espacios... Lo originario, lo primitivo, lo demoníaco, que en Europa sólo se hacen evidentes a través de los peligros de la técnica racional... aquí se representa en las amenazas de la naturaleza, en la experiencia de la luz, de la sombra, de la temperatura, del hielo, del calor. (Rivano, 1964: 119-120)

Rivano apostilló que esa impresión se tradujo que en América, "carecemos de mundo, estamos desparramados en la naturaleza". No fue de extrañar el peso de lo cultural para definir el espacio europeo, como un continuum (Borsó, 2006).

Lo transcrito de Grassi fue poner en el tapete la diferencia entre el concepto de Mundo y el de Naturaleza. El primero estrictamente 
histórico que hace posible la técnica, la cultura (Sánchez, 1992). Si Europa cuestionaba la viabilidad de "hacer filosofía" en Chile, como expresión de su avance de siglos en dominar la naturaleza y hacer del espacio urbano el lugar del pensamiento y las manifestaciones de la belleza, mostraba también no sólo el ser poseedor del patrimonio de la lógica sino la centralidad del pensar filosófico, a diferencia de la periferia que era América Latina. Un juicio y una aproximación que se reproducía en Chile -aun con este tremendo juicio adverso- entre Santiago y las regiones. El caso más evidente fue el debate en torno a la creación de las universidades regionales, donde además de cuestionar el capital social en las entonces provincias se obstaculizó en las universidades capitalinas las posibilidades de gestionar inicialmente las escuelas o colegios universitarios ${ }^{1}$.

A principios del siglo XX, el geólogo alemán Luis Darapsky, en su obra El Departamento de Taltal. La morfología de su terreno y su riqueza, pudo reafirmar la percepción europea sobre el desierto de Atacama: "El desierto carece de historia. Ni siquiera posee tradiciones". Hacia 1963, el historiador del salitre, Oscar Bermúdez Miral, registró, en su Historia del salitre, que ni las poblaciones antiguas ni la moderna industrialización salitrera y cuprífera, "han modificado lo más mínimo el paisaje del desierto" (González, 2009). El refugio era, entonces, la ciudad. Pero, además era la apertura hacia otra aproximación a la naturaleza/cultura. Para los hombres de letras del norte, la naturaleza potente y definidora constituía un todo con el quehacer humano. En el norte se apreciaba el reflejo del drama latinoamericano en toda su dimensión. El predominio de la naturaleza y el problema de la "orientación" humana. Precisamente, teniendo en cuenta las fundaciones universitarias de 1956, Lucy Casaly, una mujer de Antofagasta, con penetrante intuición sociológica, consignaba en 1961:

La provincia de Antofagasta, cuna y asiento de riquezas y eslabón primario de brillantes hechos históricos, permaneció por largos años encajonada en una existencia de opacos

1 Un protagonista de la erección de la primera universidad en Antofagasta, Gerardo Claps Gallo, primer Rector de la Universidad del Norte, anotó: "Por el lado de los estatales, estaba la indisimulada oposición del Rector de la Universidad de Chile, Juan Gómez Millas, quien sostenía que el medio provinciano, específicamente el antofagastino, no estaba apto para permitir el desarrollo de una verdadera universidad. A lo más, según él y su Consejo Superior, podía pensarse en Colegios Universitarios con carreras cortas, para profesionales intermedios... dentro de la Compañía de Jesús no faltaron quienes vieron una imprudencia en el lanzamiento de una iniciativa pro Universidad del Norte, condenada al fracaso y, por ende, al desprestigio" (Claps, 1996: 12). 
contornos, de limitados horizontes, pero hoy su gente e instituciones se han abierto en floración de nuevas y pujantes formas de vida, sus ansiedades e inquietudes son más permanentes y profundas en el campo de la cultura y de la economía y su vinculación con el mundo es doblemente palpable. Es más física y más espiritual. No obstante, la esterilidad del paisaje puso una nota tensa en el pensamiento y en la angustia de sus habitantes. Uno de los rasgos típicos determinantes de la personalidad del hombre nortino es, sin duda alguna, su dependencia del medio geográfico. (7-9)

La antinomia no era historia versus naturaleza, sino aquella que Merleau Ponty planteó entre el "espacio geométrico" y el "espacio antropológico". Es la diferencia más notable de lo percibido en el septentrión del país. Designar la toponimia, como lo hizo Francisco de San Román (San Román, 1896) en el siglo XIX, constituyó el inicio de la apropiación del espacio hacia la constitución de un territorio. El lenguaje junto con la técnica fueron las expresiones humanas de asentar cierto dominio. La historia sobre la naturaleza. Sin embargo, señorío y desertar eran planos dialécticos de entender el habitar humano en el espacio. Transformar éste, como diría Heidegger, en lugares donde se asentaba el hombre como posibilidad de construir y seguidamente de habitar (Heidegger, 1997). Desde este ensimismamiento el hombre del norte chileno observó el páramo, la alteridad desafiante como lo expuso Ortega y Gasset. El espacio está fuera de nosotros y establece la alteridad. Nuestras ideas construyen el mundo, nuestro mundo. A partir de esta introspección, el ensimismamiento, podemos fijar nuestros planes de acción sobre lo ajeno, lo otro, la alteridad (Ortega y Gasset, 1939). Pero, es para pensar sobre su propia historia ligada con la existente, truncada o no, con la desenvuelta lejos de la ciudad.

Una historia que refleja una lucha permanente. Nicomedes Guzmán (un antofagastino nacido en 1914) pudo apreciar, al enumerar un listado de escritos y autores nortinos, que ese "conocimiento más o menos cabal de Chile" (17) proviene también de la información emocional, humana y geográfica de los novelistas:

Un sentido permanente de lucha, de aguerrida beligerancia, de feroz brega, le define como un ser que existe envuelto en una atmósfera de eterno desplazamiento hacia la creación de un 
sentimiento y una conciencia sociales de vida. No se trata ya de la explotación del hombre por el hombre, así, simplemente, sino de la función de vivir en permanente pugna con el medio implacable. (17)

La ciudad y el entorno natural fueron para los nortinos tanto materialidades como simbolismos. En la primera se cobijó la racionalidad, la prensa, la institucionalidad que está unida a lo que acontece en la pampa, donde la lucha contra la naturaleza (agua, recursos, asentamientos, conectividad) es también reafirmación del predominio de la cultura, por más precariedad que posea en su dependencia del modelo productivo de su hinterland. Pero, al igual que Heidegger ascendía a las montañas para deleitarse del lenguaje del pueblo, de la gente sencilla, para comprender lo auténtico; los intelectuales nortinos, no pudieron emplear las categorías europeas -léase, la de Santiago- para construir su reflexión total sobre desierto/ciudad, pues gran parte de las claves de su meditación estaban esparcidas en el espacio de la pampa salitrera (los jirones de la historia social, las fichas salitreras, los testimonios orales, la pulpería, las huelgas, los códigos privados, es decir, el vocabulario salitrero), por lo que la antinomia ciudad/desierto no fue total, según la perspectiva que se adopte del significado de la ciudad y su racionalidad (Lezama, 2005).

El crítico Ricardo A. Latcham precisó en 1964 que el ensayo en tanto género literario no sobresalía en nuestro país si se le comparaba con México, Perú, Argentina o Brasil. Faltaban incursiones sobre el diagnóstico del carácter nacional y de los distintos tipos humanos, los cuales seguían "siendo bordeados, pero no encarado a fondo por los ensayistas posteriores a Palacios, Encina, Alberto Edwards y Benjamín Subercaseaux" (Latcham,1964). Dos años antes, en un recuento del género en Chile, Raúl Silva Castro (1962) era menos rotundo en cuanto su cultivo en el país. Situaba sus comienzos con Camilo Henríquez, aduciendo que sus escritos periodísticos asumían la "forma de ensayo". Pero dicho criterio no integró a los numerosos ensayos de Sabella, González Zenteno, Urzúa. El norte no poseía reconocimiento en el género.

Aun así hubo un intento por desvelar este ocultamiento hacia la ensayística nortina que llevó a cabo un puñado de escritores que en el norte grande acomodaron sus reflexiones sobre el territorio y su cultura en términos de una reivindicación de su paisaje, su humanidad, sus 
lugares urbanos, en fin, su aporte a la economía y a la cultura nacionales. Con este quehacer, los escritores nortinos pudieron rescatar para el panorama de las letras chilenas, los fragmentos como todo ensayo lo es, lo diferencial que constituye en la idiosincrasia nacional el ser nortino, como carácter psico-social diseminado en variados tipos humanos.

Es a nuestro entender, una re-lectura de estos autores la que va a poner en evidencia la deuda del país por la contribución regional en el devenir de la historia socio-económica. La revisión regionalista pasa revista a determinados acontecimientos históricos que son mencionados o incorporados en la ensayística nacional, desde una óptica centralista. Podría decirse de cierta utilidad geográfica nortina al cuerpo territorial. La ensayística nortina sitúa los acontecimientos históricos en el contexto físico del páramo, la de los fenómenos naturales se revelan (camanchaca, terral, espejismo), como hemos expuesto en otro sitio (González, 1983), lo cual exige el empleo de un lenguaje que pueda acopiar no sólo lo lógico y racional de dicho aporte demográfico y económico sino el acento en lo simbólico y emocional, para transmitir sentimiento, empatía y profunda afección por la naturaleza. Al lenguaje de lo exigido por un recuento historiográfico, la escritura nortina adicionó las metáforas, las imágenes de la lírica local, leyendas para hacer comprender a los mismos lectores de la ensayística nacional, la defensa de la tierra y del hombre. Los factores que han permeabilizado al nortino en el tiempo, el clima, el paisaje, sus recursos naturales y cómo han influido en la habitabilidad de la pampa salitrera, que moldeó su ser en el contexto nacional. No olvidando la diferencia en el espacio nortino, entre la pampa y los valles verdes de Arica y su interior. Esta obra ensayística constituyó un esfuerzo por subrayar la dimensión humana, estética y ecológica habida en el norte grande. La sociedad nacional sólo conocía, parcialmente, el nivel de su historia económica, precisamente, por el desarrollo del ensayo tanto historiográfico como socio-económico.

Y esto apunta a rastrear dos aspectos importantes de lo realizado en el territorio nortino. Uno, a situar la ensayística nortina en el marco temporal del género en Chile y las temáticas abordadas y dos, a contextualizar la situación del Norte Grande de cara al centralismo, dado la aflictiva condición económica-social en que se debatía después del quiebre de la hegemonía minera salitrera y sus efectos comerciales y en las condiciones de vida. Los autores que van a mentar sus ideas sobre otra naturaleza, los verdes valles de Arica, también asumieron la inquietud por el terruño, 
procurando otear en su historia colonial -una diferencia notable con los antofagastinos e iquiqueños- un pretérito de esplendor de riqueza agrícola y de tránsito entre las tierras altas y las bajas. En este encuadre habrá que situar la escritura nortina puesto que permite comprender la flexibilidad del uso del género en cuanto a planteamientos y explicaciones de la historia global del Norte Grande.

\section{Los contextos de la emergencia de la ensayística nortina contemporánea}

Parafraseando a Germán Arciniegas, el Norte Grande constituía una historia y geografía problemática para el país en general. El género ensayístico brindó las posibilidades de acometer todos los aspectos que los autores nortinos estimaron oportunos cuestionar del presente como interpretación de un pasado. Para ello fue fundamental como aconsejaba Henríquez Ureña (Aínsa, 2005) el cómo decir a la comunidad extra-regional lo que había sido el pasado glorioso nortino, con sus ciudades deslumbrantes, globalizadas por la industria, las grandes casas comerciales europeas y los clippers calicheros que llevaban el nitrato de sodio a los mercados mundiales. Un pasado que los nortinos conocían vivencialmente y que parte de esa historia estaba en sus calles, teatros, casas y viejos muelles. ¿Cómo encarar inicialmente que los cimientos de la historia social del proletariado, con su conciencia de clase, sus aparatos culturales y asociativos, con sus emblemáticas huelgas y masacres no tuvieran todavía en los manuales de historia las explicaciones pertinentes o, por el contrario, cómo ulteriormente, después de haber aportado a las arcas fiscales las mayores divisas provenientes del salitre por más de cincuenta años, el Estado, ahora, llamado de compromiso, olvidara a las provincias de Tarapacá y Antofagasta y no hubiera un plan razonado para acometer soluciones ante el deterioro de la calidad de vida de sus habitantes?

Son estas dos preguntas medulares que atraviesan las páginas de los ensayos nortinos. La problematización del tema nortino tuvo diversas aristas. No es solamente el cuestionamiento a la realidad presente, sino también poner de relieve que la escritura ficcional que llevan a cabo siguiendo las corrientes literarias en boga, principalmente el neorrealismo de la generación del 38 (Madrigal,1976; Guerra, 1987) les ha dado reconocimiento como escritores y constituye el argumento que 
refiere de la geografía, de la lucha humana contra lo inhóspito, la épica obrera, en Sabella, Bahamonde, González Zenteno, para devenir en intelectuales que procuran en sus ensayos tentar interpretaciones sobre lo evocado en su obra narrativa.

Si oteamos el panorama del ensayo en Chile en el tiempo que discurre desde 1947 hasta 1970, encontramos las huellas que van a impregnar al revisionismo historiográfico sea de corte conservador hispanista, cuyo adalid fue Jaime Eyzaguirre, que escribe Fisonomía histórica de Chile, en 1948, y proseguirá su visión cuestionadora de la historiografía liberal positivista. Pero, hubo un revisionismo de talante progresista marxista cuyos inicios se remontan a la figura de Marcelo Segall, con su Desarrollo del capitalismo en Chile. Cinco ensayos dialécticos, de 1953. Labor proseguida por Hernán Ramírez Necochea, Julio César Jobet. Hay que adicionar el nombre del antofagastino Floreal Recabarren Rojas, con su Historia del proletariado en las provincias de Tarapacá y Antofagasta, en 1954. El revisionismo historiográfico de ambas vertientes tuvo sus seguidores mientras sus cultores principales continuaron brindando estudios y ensayos durante la década de 1960 (Gazmuri, 2009). Pero, también el ensayo recogió la reflexión sobre la conciencia latinoamericana en procura de una expresión genuina, a veces vinculada con la tradición occidental como se percibe en Jorge Millas, Clarence Finlayson, o buscando una originalidad de la existencia continental como lo acomete Félix Schwartzmann (Sánchez, 1992; Vidal, 1977). En aquello años, 1950, un antofagastino, Martín Cerda, se formaba en Francia con los principales pensadores (de la Puente, 2010). También hubo una ensayística que abordó los temas del subdesarrollo, el progreso económico y la integración continental, figurando de modo destacado Felipe Herrera, Alberto Baltra, Jorge Ahumada, Aníbal Pinto (Devés, 2003).

Empero, el ensayo nortino si bien procuró, en puntuales casos, arroparse de la documentación necesaria para avalar sus interpretaciones, no pudo evadirse de uno de los rasgos que caracterizó a la producción ensayística nacional dentro del encuadre temporal que hemos situado nuestro análisis: el "ensayo crítico-impresionista" apoyado en intuiciones, sin recurrir a las ciencias sociales (Pinedo, 1987).

En esta mirada crítica hacia el pasado se alzaban en el horizonte de la pampa avances regionales que durante el ciclo salitrero la sociedad 
regional cosmopolita logró allegar como la modernización y los impactos de la modernidad en sus ciudades y puertos a contrapelo del epicentro político. No obstante, tales resultados debían situarse como parte de la lucha constante del nortino. Un combate sin tregua contra la adversidad de su geografía, de los ciclos de bonanza y depresión económica y de la tensión de construir una urbe frente a la tentación informal de los campamentos mineros. Ahora, como consecuencia de la falta de previsión fiscal por los recursos salitreros y de la desidia estatal por atender el desarrollo socio-económico del Norte Grande, se asistía a una desmoralización general de la población. Desmoralización que no se tradujo en apatía sino por el contrario en agonía -en el sentido etimológico- regionalista que lucha por el mejoramiento de su calidad de vida. Precisamente desde 1948 se organiza en Antofagasta el Centro para el Progreso con José Papic y Ramón Yoma. La iniciativa se derramó como aceite en el mapa de la zona, Calama, Mejillones, Iquique, etc. Hacia fines de la década de 1950 se crea por ley la Junta de Adelanto de Arica. Paralelamente, en el campo político-legislativo, dos preclaros nortinos, el antofagastino Juan de Dios Carmona, diputado falangista, y el calameño Radomiro Tomic Romero, senador de igual tienda, dieron forma en la década de 1950 a la Unión Parlamentaria del Norte, para defender las viejas provincias salitreras. Idea que recibió el respaldo decidido de los parlamentarios nortinos, como Jonás Gómez Gallo, o foráneos pero referentes ideológicos de sus partidos, Salvador Allende y Raúl Ampuero, Fernando Alessandri, Víctor Tapia, etc. La reconquista de los recursos naturales para el dominio del fisco de Chile, comenzó a tener forma con los resultados de las denominadas leyes del cobre, cuyos beneficios se conocieron hacia fines de la década del 50 en la región nortina. La lucha contra el centralismo logró algunas conquistas en el gobierno de Ibáñez del Campo, como el Puerto Libre para Arica en 1953 y las zonas franca industrial y alimenticia para Arica y Antofagasta, hacia fines del decenio. Las prerrogativas regionales tuvieron en la Universidad del Norte, creada por ley en 1956, en Antofagasta, los apoyos académicos en sus sedes de Arica e Iquique, donde nuestros autores, por ejemplo Sabella, Bermúdez, Wormald, encontraron la cobertura para sus obras, mientras las sedes regionales de la Universidad de Chile, Antofagasta y Arica, brindaron apoyo similar, en el caso de Bahamonde, que desenvolvió una labor titánica. Las revistas universitarias como la Revista del Norte, Anales de la Universidad del Norte, Áncora y Revista Universitaria, se 
sumaron a las gestiones individuales llevadas a cabo por Andrés Sabella con su revista Hacia, desde 1953, o por Enrique Agullo con su Anuario Antofagasta, que acogieron breves ensayos para difundir la historia, las letras, el patrimonio y la economía del norte chileno. La Universidad de Chile se ocupó de ventilar en notables seminarios regionales las múltiples problemáticas sobre el recurso hídrico, la industrialización, la educación; en fin, de la calidad de vida, llevados a cabo en Tarapacá y Antofagasta, desde 1956.

Para estos autores se vivía en la década de 1950 el ocaso definitivo de la industria salitrera, con el cierre acelerado de las oficinas que laboraban con el sistema Shanks (González, 2002). De ahí la insistencia de Sabella de rescatar el patrimonio salitrero-cuprero en un gran Museo del Cobre y del Salitre y en la creación de un Boletín Cultural del Norte de Chile en 1956, el cual promovía todo un programa de incentivo del ensayo, pues, refiere Sabella:

Reflejaría todas las manifestaciones históricas, literarias, artísticas, etc., de nuestra zona y que aparecería dos veces al año (en junio y noviembre), sería dirigido por un Consejo de Redacción y demandaría, de preferencia, aportes de Arica a Copiapó, centrándose, naturalmente, en nuestra ciudad el foco de su radiación, sin excluir colaboraciones de escritores nacionales y extranjeros que mantuvieron relación con nuestros propósitos. (330)

\section{Lo diferencial de la ensayística explicada por la filiación y la afiliación}

Edward Said en 1984 (Said, 2004) emplea la diferenciación entre filiación y afiliación para determinar cómo la crítica surgida del ensayo, está condicionada por dicha distinción. Así, todo lo que nos es dado al nacer, como por ejemplo el grupo familiar, correspondería a la filiación, en cambio aquello que elegimos, como por ejemplo la militancia política, correspondería a la afiliación. De esta manera, todo texto está situado -y responde-a un contexto histórico. Y como texto mundano-situado en el mundo- provoca algo con su lectura. Y lo obvio es su repercusión en el momento histórico en que se pronuncia e interpreta, tanto para los que comparten su filiación, nortinos, pampinos, antofagastinos, iquiqueños, taltalinos, tocopillanos. Y que, generacionalmente comparten casi los 
mismos horizontes y sentidos vitales, como también para aquellos que, no siendo nortinos, asumen por militancia ideológica las convicciones de la lectura y participan del estilo del discurso.

Los autores nacidos en Antofagasta, Taltal o Iquique, como Andrés Sabella, Mario Bahamonde, Óscar Bermúdez, Luis González Zenteno, van a tener una vivencia con el pasado salitrero sea por haber incursionado en la temática salitrera en sus novelas o cuentos, que inaugura Sabella con Norte Grande. Novela del Salitre, en 1944, y por consiguiente sus relatos dieron cuenta, como hemos afirmado en líneas superiores, de una argumentación sobre la vida cotidiana de las oficinas salitreras, pulperías, fichas, lucha, prensa obrera, etc., por lo que, la emergencia de la historiografía social de corte marxista coincidió en sus interpretaciones con lo expuesto en sus obras de ficción. Pero no todos centraron su análisis en el pasado calichero. Se trata de autores cuyas referencias a la industria del salitre discurren alejados de la historia social pero se hacen cargo de la vida marítima plétora en imágenes de una bullente actividad comercial y un aire cosmopolita urbano-portuario, como lo constatamos en el acercamiento de Salvador Reyes con sus Andanzas por el desierto de Atacama, nostálgico del mundo clásico salitrero o de Carlos Sander con su obra Entre la pampa y el mar, de 1963, sobre la cosmovisión calichera de las oficinas del sistema Guggenheim, de corte más comprensivo del criollismo paisajístico. Otros ignoraron, condicionados por sus lugares de residencia, v.gr. Arica, la historia socio-económica que permite entroncar al norte con el desarrollo político-institucional y el progreso económico en base de la minería mono-productora. La reflexión sobre Arica llevada a cabo por Luis Urzúa con Arica, puerta nueva. Historia y folklore, de 1957, y Alfredo Wormald con Frontera Norte, de 1963, buscaron, entre otros motivos, resaltar la antigüedad de la actividad agrícola de sus feraces valles en torno a una ciudad de prosapia colonial con escudo otorgado por el imperio español, acogiendo de modo marginal la actividad minera de Huantajaya. Es un lugar asimétrico en el conjunto de las ciudades nortinas.

Otra atención encontramos en autores oriundos de Iquique, como Freddy Taberna con Algo sobre las comunidades andinas en Tarapacá, de 1968, muestra de comprensión y racionalidad respecto a la planificación del desarrollo territorial de Tarapacá. Son apuntaciones que responden, tanto al rescate de lo andino en el encuadre de un desarrollo endógeno, como a las preocupaciones de fines de los 60. 
La producción ensayística, como ha puntualizado Liliana Weinberg, respondió a una ecuación que hasta mediados del siglo XX, para el caso nortino extensivo para los largos años 60, mostró “un pacto implícito de representatividad entre el ensayista, los temas, el público, el mundo del libro y su articulación con otras esferas del quehacer social", donde la escritura estuvo ligada al mundo de los valores, la "forma de la moral" (Weinberg, 2007). Todas las formas son empleadas en el discurso o se apela a ellas. En el ensayo nortino encontramos el uso de la metáfora y la poesía, la evocación personal con el documento testimonial, la incorporación de la oralidad y la tradición popular con lo referido por la prensa, la monografía. Como forma libre de presentar lo que se desea "comprobar"-como lo valida el término griego exagion (Moll, 2000)- se observan en el ensayo nortino con la finalidad de interpretar nociones que en el lenguaje nortino o en los códigos privados de actividades sea salitrera, cuprera o pesquera, tienen un valor, un peso, que no guarda concordancia con su empleo fuera del territorio septentrional, como "ser", "empampado", "espejismos", "oficina", etc. La forma libre hace que el ensayista pueda en su interpretación "mostrar" y no "demostrar" sus argumentos.

Establecido lo constitutivo de lo diferencial entre la ensayística nortina con la nacional y dentro de ella los matices que se desprenden no solamente de sus historias biográficas sino de las historias que responden a los condicionantes de la geografía minera o agraria, demos cuenta del recuento de autores y temas que aborda.

\section{Los autores nortinos coincidentes por generación y afiliación}

Las obras de Andrés Sabella Gálvez (1912-1989), Luis González Zenteno (1910-1961) y Mario Bahamonde Silva (1910-1979) coinciden tanto por formar parte de la generación literaria del 38 como por compartir la ideología marxista. El empleo del lenguaje por esta generación moldeó materiales de enorme opacidad, pero plenos de simbolismo ideológico, como son las huelgas, las masacres y las persecuciones. No escapó a esta producción ensayística el dotar de una interpretación a todo el universo ficcionalizado.

Sabella da a conocer su Semblanza del norte chileno, en 1955, en la "Colección Saber" que dirige Clodomiro Almeyda en la Editorial 
Universitaria. Un vademécum para orientarse en el norte, donde no debe sorprender al lector el caudal de imágenes, propio de un poeta como es Sabella, por antonomasia diría Neruda, poeta de Antofagasta. En nueve capítulos recorre la historia social y económica, deteniéndose en personajes fundamentales, populares como empresarios, de la historia industrial. Los capítulos refieren: 1. Sustancia y emoción del norte Chileno, 2. Cosas del norte, 3. De la leyenda a la industria, 4. 1866-1891, 5. El pampino, 6. El empampado, 7. Pausa de plata y cobre, 8. La lucha obrera y 9. Capitanes del norte. Todo lo puede la pampa, según Sabella, pues acogió bandidos de cuchillos, como Silverio Lazo "El Chichero", a empresarios lindando con el saqueo, como John Th. North. Una página de Semblanza permite ubicarnos en el sentimiento central de la nortinidad comprendiendo y explicando la desemejanza ontológica que encara el nortino, el empampado:

En imagen y realidad, el Norte es la cabeza de Chile. Cabeza de frente rotunda, por ella se desplaza el sol más brioso que hayamos admirado jamás, un sol dueño de sí y de los horizontes de la pampa: patria de las piedras que parecen lágrimas de Satanás y patria, también, del espejismo: la hermosa máscara de la muerte... Universidad para Endurecerse en Hombre ¡Bella y poderosa cabeza, la de nuestra patria! Su erario dependió, magníficamente, del sudor de los "ripiadores" y "paleros" de Tarapacá y Antofagasta y Taltal. Chile sembró en sus "rajos". Y en los "rajos" se rehízo el chileno, brotando una faz aguerrida, de inconfundible masculinidad: la del pampino...empezaban a desteñirse el temor y el respeto "al rico". La máquina contribuía en lo demás. La lucha social, de este modo, repartíase y era el corazón la sola energía que desbarataba el enjambre de las balas, si no, ique lo atestigüen los muertos de las masacres de 1890, de 1906, de 1907, de 1921 y de 1925! El norte social de la república lo fijó esta cabeza amarilla, impregnada por salvia solar. (Sabella, 1986: 7-9)

Empero, Sabella desde esta mirada de naturaleza adversa orienta un aporte al pensamiento social nacional y a la contribución de una imagen de Chile más republicana y democrática (González, 2007).

El momento histórico era proclive para atraer la atención hacia el norte chileno. Se iban conformando las ruinas de oficinas paralizadas 
pocos años atrás. El poblado de Pampa Unión comenzaba a deshabitarse rápidamente. Era un grito de rescate del pasado memorable como lección de nortinidad y señal del "pago de Chile".

Sabella insistirá en esta simbiosis entre los vestigios monumentales de los "pueblos fantasmas" y la necesidad de la memoria histórica, respecto no solo del quehacer en la pampa sino en la tarea humana de permanecer, "otorgar a la ciudad el soplo del espíritu" (Sabella, 1957: 324).

Mario Bahamonde comenzó a tentar breves ensayos periodísticos en la década de 1950 y algunos de mayor aliento en Ancora en los años 60 y en sus antologías (Bahamonde, 1966, 1969). Su ensayo mayor -Pampinos y Salitreros- lo había iniciado en apuntes y documentos a mediados de los 60 cuando decidió publicar una colección de obras nortinas desconocidas o de difícil localización en las bibliotecas nortinas, como de Matías Rojas Delgado, editado en 1883, El desierto de Atacama y el territorio reivindicado, editado en 1883, en Antofagasta, verdadero fundador del ensayo del Norte Grande², como lo fue José Joaquín Vallejos del ensayo nortino, antes de que la guerra del Pacífico hubiese provocado la anexión de gran parte de Antofagasta y la totalidad de Tarapacá. Finalmente, lo acopiado en los años 60 dio lugar a Pampinos y Salitreros, en 1973, periodo de la más difícil coyuntura histórica del siglo XX. Bahamonde nos refiere la pesadumbre por el olvido de las tradiciones y del patrimonio precolombino, colonial y republicano. En 10 capítulos pasa revista a los jalones de la historia social y económica nortina: 1. Los aventureros de la sed, 2.Los soñadores de la sal, 3. Los puertos del salitre, 4. El negocio de los salitreros, 5. Los negociados, 6. Imagen morena del pampino, 7. Los hombres de la lucha, 8. Las fichas pampina, 9. La lucha obrera, 10. Recuerdos inútiles. Anota:

El nortino, como expresión regional de tipo humano, existe y ha existido siempre, aunque para el resto del país este concepto diferencial no resulte muy claro. El nortino, en su legítima calidad de habitante regional, no es hijo del diaguita ni del atacameño ni del quichua ni del aimará, que caminaron

2 Bahamonde, consigna el fundamento de la prédica regionalista de Matías Rojas, como soporte del ensayo nortino: "Así era la mentalidad del país: política y centralista. Nada le podía importar al hombre del centro de mentalidad política lo que sucediera en las orillas de su geografía, mucho más si estas orillas se perdían en las dunas sedientas de un desierto ajeno a su conocimiento, a su interés y a su provecho y en cuya leyenda deambulaba la muerte con su terrosa cara de soledad. Desde entonces a hoy, para participar en la lucha del desierto ha sido necesario vivirlo". (1962:10-11) 
por estas serranías en la añoranza ancestral del tiempo...El nortino es hijo de la aventura y no de la tradición. Pero es un hijo legítimo, con todos los honores del aventurero, desde los remotos abuelos españoles hasta los más recientes transeúntes del destino zonal. Y lo que ocurre es que, además de ser hijos de la aventura, son hijos del olvido, lo que es peor. Y esta condición de olvidadizos nos empezó junto con nuestros primeros habitantes zonales. (Bahamonde, 1973: 5)

El escritor iquiqueño Luis González Zenteno (1957) sostuvo, con plena autoridad, esta fusión entre el hombre y la naturaleza como clave para poder comprender la disolución de la frontera entre la historia y la naturaleza. En su ensayo más pertinente al tema que estamos tratando, "El Norte Grande: Su medio y su gente", planteó la apariencia y realidad de esta intrincada relación:

Uno piensa frente al yermo: "El hombre ha de ser aquí duro como la naturaleza". Se asocia siempre la vegetación al optimismo y la fertilidad a la magnificiencia. Y, extraño, el hombre nortino es cordial y generoso, con la sonrisa a flor de epidermis (41)...El salitre sustenta esta franja de territorio desde Arica a Antofagasta, mueve el comercio, las grúas, los barcos e identifica al hombre con el páramo. Lo amarra a él indisolublemente. Por eso, los cuidadores vigilan con fidelidad perruna las Oficinas paralizadas. Y no es por celo excesivo. Es que se sentirían extranjeros en otro lugar. En cambio, en el páramo está la unidad fantástica del hombre con el yermo, que nace y se robustece en las blanduras de las dunas, del espejismo, de los salares, en los brazos retorcidos de los tamarugos y en el espacio límite. (49)

\section{Los autores nortinos no coincidentes por generación y discrepantes por afiliación}

Fue Óscar Bermúdez Miral (1906-1985) con su ensayo El drama político de Chile, de 1947, el que se apartó de la focalización de la temática nortina, y en cambio tentó una visión ambiciosa del cuadro político, económico y social del siglo XX. Siendo una mirada que juzga sin contemplaciones las acciones de los gobiernos. Constituyendo un escalpelo que se esgrime desde la región nortina. 
Para Bermúdez, las dos tendencias básicas de la evolución chilena -“conversión hacia un socialismo moderno; estabilizar un sólido concepto de Autoridad- representan las dos columnas del edificio futuro ante cuya erección debe resolverse el confuso drama social de Chile" (Bermúdez, 1947: 11-10). No escapa a su diagnóstico que la inferioridad económica de las grandes masas provocaba la "inferioridad biológica, la inferioridad social y la inferioridad cultural".

Su reflexión era de un iquiqueño y militante socialista que confiaba que la crisis moral que nos afectaba debía resolverse por un nuevo espíritu, un asunto de sensibilidad, es decir de "juventud" (Bermúdez, 1947: 173).

En la década de 1950 comenzó su labor como historiador en las páginas de la Sociedad Chilena de Historia y Geografía. Entre sus obras historiográficas de la década siguiente, acomodó una serie de ensayos menores en las páginas de la revista En Viaje, de la Empresa de Ferrocarriles del Estado, destacando dos ámbitos de interés: la historia vinculada con el salitre y aquellas decisiones que mostraron imaginación y, por contraste irónico, indicaba la carencia de innovación en nuestros hombres públicos. En uno de ellos estampa: "Hace casi 200 años, (el Virrey) Amat, preocupándose de la minería y la agricultura de la zona, acogió las insinuaciones de los vecinos importantes de San Lorenzo de Tarapacá y ordenó que se estudiasen los medios conducentes a ampliar las posibilidades de agua en esa quebrada" (Bermúdez, 1962: 24). Bermúdez recorrió decenas de veces toda la pampa salitrera de las dos provincias. En uno de sus recorridos pudo consignar que las tierras desérticas otorgaban al hombre una "extraña sensación de libertad", despojando a la existencia de preocupaciones: "Nada sujeta el pensamiento; la mirada suelta vaga libremente a ras de la tierra desnuda, se dilata hasta el horizonte o recorre la suave curvatura de los cerros encarnados y grises" (Bermúdez, 1965: 16).

El desconocimiento de la historia del norte se levantaba como un reto y paradoja a la vez. Tanto había aportado el Norte Grande en lo económico, social y demográfico al país, y el Estado no se interesaba en subsanar dicho silencio. En su ensayo sobre los Orígenes históricos de Antofagasta, estampó palabras que todo nortino asumía como propias: "Establecer los orígenes históricos de esta ciudad, tiende a satisfacer una necesidad cultural del país" (Bermúdez, 1966: 11). 
Ante la figura y obra de Bermúdez se erigió como antítesis Salvador Reyes (1889-1970). Copiapino de nacimiento, vivió su infancia y adolescencia en Antofagasta. Fue el principal exponente de la corriente literaria imaginismo, destacando la ambientación marítima en su prosa. Su sensibilidad política fue más cercana a las posiciones conservadoras.

Su obra Andanzas por el desierto de Atacama publicada en 1969, al igual que la obra acumulativa de Bahamonde, constituye un caleidoscopio de incontables viajes hacia el norte, principalmente en la década de 1950 como lo refiere en su libro. Es un libro único de fervor de nortinidad. Nada escapa a su visión. Rastrea desde Copiapó, "puerta del desierto", un viaje de 1936, pasando por todos poblados precordilleranos -es el más insistente viajero de los faldeos cordilleranos, que retrata personajes, describe sus monumentos históricos como sus santuarios naturalesdesde Toconao hasta Pica, señalando los efectos de la crisis en Taltal y Antofagasta. Es un libro que se inicia y se clausura en la vivencia personal. Los pocos documentos son para fundamentar la historia de Antofagasta. Su tono dialogante $y$, a veces intimista, se grafica en su primera página:

No sé si todas las personas, cuando, sin ser aún viejas, ya han dejado de ser jóvenes, ven la infancia y la adolescencia envueltas en la magia en que yo las veo; no sé si en todas, las impresiones de los primeros años de la vida se reaniman con la misma fuerza que en mí, si ciertas músicas, ciertos olores, los reflejos de un crepúsculo de fines de invierno, dan a las otras personas la impresión de volver atrás en el tiempo y de revivir los momentos de antaño con una realidad penetrante que, sin embargo, tiene mucho de alucinación... No sé si a las personas que están más cerca de mí les ocurre esto mismo. Nunca hemos hablado de cosas tan confusas, tan subjetivas, que parecen imposibles de aclarar en una conversación...Por mi parte, me alejé pronto de los pueblos en que transcurrieron mi infancia y mi adolescencia, y no volví a ellos sino siendo ya hombre. Encontré grandes cambios, para bien o para mal, pero ellos eran sólo físicos. Mis lazos espirituales con Antofagasta, Taltal, las salitreras, los oasis, las caletas, subsistían intactos. Sin embargo -nueva contradicción-, allí encontré la medida exacta del tiempo transcurrido y el testimonio melancólico de no ser ya el que fui... Una calle de Taltal, el Lincancaur rojo en el crepúsculo, los viejos muelles de Antofagasta, la desolación 
de Paposo, la pampa envuelta en la camanchaca del amanecer, se me aparecían como los únicos escenarios auténticos de mi vida. Lo que me separaba de ellos era el tiempo infinito cuyo latido percibía claramente sin que por eso me liberara su secreto. (Reyes, 1969: 13-16)

No existe, a nuestro entender, una escritura nortina que dé cuenta con más cercanía, de evocación y memoria, de lugares de la costa, la pampa y poblados precordilleranos, con un acento más personal, que este libro de Salvador Reyes.

El más viajero de los escritores nortinos, el de vida cosmopolita, por su condición de diplomático, pidió un pedazo del viejo muelle Barnett para confundir sus huesos con el elemento más destacado en su obra novelística: el mar.

\section{Los autores nortinos no coincidentes por generación y si por afiliación temática local}

Destacamos bajo este rótulo los nombres de Carlos Sander (19181966) y César Díaz-Muñoz Cormatches (1928-2002).

Sander era un poeta con una obra publicada y reconocida en España, en los años 1953-1957, donde terminó siendo cónsul en Madrid, después de ejercer la dirección de El Mercurio de Antofagasta. Director del periódico en referencia, cuando todavía estaba bajo la propiedad de la Anglo Lautaro Nitrate, acometió el ensayo que nos ocupa: Entre la pampa y el mar, compuesto de 103 páginas, dividido en trece capítulos: 1. Insomnio de Antofagasta Dormida. 2. Los Pueblos de la Pampa. 3 .La Montaña Mágica de los Indios Chucos. 4. El Anfiteatro del Cobre. 5. En las Huellas del Metal Escarlata. 6. Una Luz en el Desierto. 7. Los Hombres del salitre. 8. Mediodía en Pedro de Valdivia. 9. Nocturno en María Elena. 10. Vergara Mira hacia Lagarto. 11. Alba en Coya Sur. 12. El Salitre en la "Caleta de Duendes". 13. Cobija, el Puerto del Silencio.

La mirada hacia la pampa se recrea por la atención hacia las huellas y vigencia de la industria y los asentamientos del salitre. Importa destacar los marcos en que sitúa el esfuerzo titánico -“algo que siempre debemos señalar con énfasis: la lucha del hombre con la naturaleza... cómo el hombre ha ido avanzando poco a poco en su afán de descubrir todo lo que antes era inaccesible" (Sander, 1963: 23)-, y por ende en el eje 
pampa/ Antofagasta está la hermenéutica para explicar todo lo acaecido. La naturaleza del desierto es la conservadora de los acontecimientos que la urbe ha develado:

Nos ha comunicado su sapiencia antigua y veraz y nos ha contado cuentos, tradiciones y leyendas, mostrándonos a todos los hombres que la hicieron grande, libre y gran señora del Norte Grande. Nos ha musitado el nombre de los próceres civiles y militares, de los héroes del pensamiento y de la espada. Todo eso lo llevamos en este momento emocional y permaneceremos inmersos, acariciando nuestro cuerpo con fechas, batallas memorables, escritos definitivos, poemas que cantan a la belleza y luchas donde siempre el nombre de Chile, brilló con un colorido de fuego pertinaz... En esta noche, hemos velado las armas junto al rostro de Antofagasta y hemos renovado los juramentos que hicimos de amar al Norte y a la patria, de consagrarnos a sus servicios, de guiar a nuestro pueblo por senderos de felicidad y de paz. (Sander, 1963: 11)

Díaz-Muñoz Cormatches, fue un especialista en derecho minero, de militancia demócrata cristiana toda su vida -“antofagastino ex corde", dirá Sabella- que retornado a su ciudad natal, fue testigo de la crisis de los años 50. El entorno le invitó para redactar ensayos cortos, algunos vinculados con el norte, donde destacamos Nuevas Escribanías. Asociando la "tiranía del medio sobre nuestras vivencias", ya en tiempos bíblicos, apunta que, "en nuestro medio el hombre está permanentemente solicitado por el esfuerzo". No tiene un ambiente- la lluvia, el verdeque lo encamine hacia el soñar, la extravagancia, lo superfluo. Aquello explicaría las limitaciones de nuestras ciudades nortinas respecto del centro y sur del país. La lluvia, una "nostalgia" para las gentes del norte, otorga la "sensación de intimidad, de calor, de hogar" inexistente en la casa nortina. Una reflexión que pone la precariedad del existir en el norte. La tensión entre el campamento, condición de tránsito del trabajo, y la ciudad, reafirmación del asiento final, se pone de manifiesto en Antofagasta: "Antofagasta, puerto principal de nuestra costa árida, ha nacido como un campamento de trabajo, y aún conserva algún signo del carácter o circunstancia de su nacimiento" (Díaz-Muñoz, 1962: 57-60; 63$64 ; 105-112)$. 


\section{Los autores nortinos no coincidentes por generación y si por afiliación temática diferencial del mundo salitrero}

En este apartado hemos ubicado los aportes de Luis Urzúa Urzúa, Alfredo Wormald Cruz y Freddy Taberna Gallego. El primero un destacado sacerdote, formador de la generación socialcristiana en el Colegio San Luis de Antofagasta y mentor del periódico El Debate, el segundo diario católico en importancia nacional. Luis Urzúa Urzúa (1901- 1971?), era poeta y su obra principal Arica, Puerta Nueva, de 1957, alcanzó éxito editorial que para 1969 enteraba su tercera edición. Es una narración generosa en registrar estampas de la vida antigua, del lejano pasado español, que Urzúa en 279 páginas y 35 capítulos pasa revista. En los primeros once capítulos se despliega la evolución de Arica, para seguidamente adentrarnos en los fértiles valles de su interior y los mágicos pueblos precordilleranos. Páginas de admiración por el altiplano, exigen al autor anotar:

Han sido siete años de andanzas por un país donde el polvo de los siglos no ha dejado sedimentos que transformen la modalidad primitiva del ambiente. Ni siquiera el rugo de los motores del avión, que a veces cruza la diafanidad de esos cielos sobre un techo de seis mil metros, consigue alterar el paso tardo de los mulares, la arrogancia displicente de las llamas o la faz inexpresiva del arriero...el interior de Arica es una isla geográfica de diez mil kilómetros cuadrados... el espíritu de la colonia mantiene sus preocupaciones religiosas e imprime una contextura original a la forma de vida. (Urzúa, 1969: 87)

Urzúa pone ante el lector los contrastes de paisajes y hombres del interior respecto a la vida ariqueña que ha logrado, a partir de 1953, con la creación del Puerto Libre, comenzar a buscar su progreso y marcar a una generación de chilenos:

Hizo subir la población de veinte a sesenta mil habitantes. Durante los siete años que duraron las franquicias portuarias todos vivieron en Chile con la obsesión de un viaje a Arica... Todos se acostumbraron a vivir mejor y a buscar continuamente modernas formas de progreso. Se despertaron inquietudes 
educacionales, curiosidad arqueológica y aficiones artísticas que han elevado el nivel cultural. (Urzúa, 1969: 11)

Alfredo Wormald Cruz (¿1903?-1981), se destacó como historiador regional. Vinculado desde sus inicios, en 1960, a la Universidad del Norte, sede Arica, atendió el devenir histórico con su ensayo, de título expresivo, Frontera Norte. La acogida del público sorprendió: dos ediciones, una en 1963 y otra en 1968. En 195 páginas, el volumen está dividido en dos partes. La primera "Las Historias" con doce capítulos, pone el acento en el pasado colonial, deteniéndose en la obra del doctor Noé. La segunda parte, "El Hombre y la Tierra”, de siete capítulos, da cuenta del pueblo aimara, Putre, los mulares. Wormald enfatiza el hecho de la mancomunidad existente entre las poblaciones del departamento de Arica y las vecinas, donde los idiomas indígenas constituyen los vehículos de la vida que se despliega en el territorio. Arica es un territorio de encrucijada por donde cruzan y se confunden razas, nacionalidades y costumbres. Es un territorio:

casi siempre tan equivocadamente interpretado y tan curiosamente ignorado por los chilenos. Ignorancia que, por supuesto, alcanza a sus razas y costumbres, a pesar de que ellas cubren en el espacio millares de kilómetros, y en el tiempo sumergen sus raíces en la profundidad de los siglos...hay que tener muy en cuenta, si es que se pretende integrarlas a la historia y a la vida total de la Nación. (Wormald, 1968: 8)

Freddy Taberna Gallegos (1943-1973), iquiqueño, geógrafo de profesión, dejó páginas sobre el espacio altiplánico de Tarapacá que denotaron su preocupación por planificar una visión sobre los recursos naturales y sus nexos con las comunidades tradicionales. Su aproximación es con el utillaje de las ciencias sociales. En 1968 escribió Algo sobre las comunidades tradicionales andinas de Tarapacá, donde registró lo pertinente a nuestro análisis:

Estas comunidades por su condición agro-pecuaria, presentan la crisis de los grupos residuales y autóctonos latinoamericanos, incapaces de adaptarse a técnicas altamente desarrolladas (17)... El hombre altiplánico se presenta en forma de pastor semi-nómada... la concentración en poblados, se reduce sólo a ocasión de festividades y a los periodos de siembra y cosechas. La vida altiplánica es un continuo vagabundeo en torno a los 
"champiales" y "bofedales" que están provistos de un pasto que alimenta a la masa ganadera andina (31)... La necesidad de educación ha venido a fortalecer la idea de pueblo. (34)

\section{Conclusión}

El género del ensayo practicado en el norte chileno en las décadas de 1950 y 1960 reparó la omisión de la literatura chilena sobre el territorio, la economía, sus gentes, sus crisis. No fue solamente una labor de reparación por el olvido de la historia social y económica del ciclo salitrero sino una representación ante el país del aporte al erario fiscal de la señalada industria y de la épica social en la pampa. El momento para plantear fue la angustia ante la crisis que azotó a las provincias de Tarapacá y Antofagasta, post salitre, y sus terribles efectos en las condiciones de vida de sus habitantes. La visión del ensayo involucró señalar la diferencia de entender la naturaleza y la historia como un todo, cuando el espacio desértico hegemónico condicionaba la forma de reflexionar sobre el habitar y la viabilidad de los asentamientos humanos. A diferencia del centro y del sur, en el Norte Grande se dio la desaparición de poblados, ya sea, por el abandono de lugares industriales o de viejas ciudades del litoral que exhibían sus restos: la naturaleza formaba parte de la propia historia. Hombre y desierto se confundían en sus relaciones dialécticas. Hoy, avanzaba la cultura. Mañana, volvía el dominio del yermo. En los valles de Arica y en los poblados de Tarapacá, la vida económica y determinadas costumbres fueron los signos de la presencia humana por siglos. La precariedad era tal que la naturaleza era omnipresente. Pero, los ensayistas mostraban que aun en ese reto a su sobrevivencia, había empatía y afecto por el terruño. La producción ensayística constituyó en el norte un hiato en el total nacional. El desinterés del centralismo político, la displicencia de los autores del centro por ignorar las páginas nortinas, guardó relación con la temática y el sentido del ensayo practicado en el Norte Grande. En Chile volvía a repetirse aquello que Hegel afirmó, en términos de que, lo que es conocido es también lo más desconocido. Un puñado de autores nortinos pudo, a través de una sólida obra de ficción mostrar otro paisaje, otros hombres a los chilenos. Ellos mismos se encargaron, por medio del ensayo, de explicarles a esos mismos chilenos, el sentido de sus escritos regionales. 


\section{Referencias bibliográficas}

Aínsa. F. (2005). Ensayo. En Ricardo Salas Astrain (Coordinador Académico), Pensamiento Crítico Latinoamericano. Conceptos Fundamentales, I, 239-265. Ediciones Universidad Católica Silva Henríquez.

Bahamonde, M. (1962). Prólogo. Matías Rojas y el desarrollo del periodismo. En Matías Rojas, El desierto de Atacama (IV), (pp. 7-14). Antofagasta: Ilustre Municipalidad de Antofagasta, Colección de Literatura Nortina.

. (1966). Notas sobre el desarrollo de la literatura nortina. En M.

Bahamonde (Editor), Antología del cuento nortino (pp.6-26). Antofagasta: Editorial Universitaria.

. (1969). El relato literario en el norte de Chile. Primer Seminario

Internacional de Literatura Hispanoamericana (pp. 79-89). Antofagasta: Universidad del Norte.

. (1973). Pampinos y Salitreros. Santiago, Chile: Editorial Nacional Quimantú.

Borsó, V. (2006). Europa y la inquietud del espacio. En Félix Duque (Editor), Buscando imágenes para Europa (pp. 129156). Madrid: Ediciones Pensamiento.

Bermúdez, O. (1947). El drama político de Chile. Santiago, Chile: Editorial Tegualda.

. (Octubre de 1962). El Virrey Amat, don Antonio O'Brien y la provincia de Tarapacá. Viaje, 383, 24-25.

. (Septiembre de 1965). Viajando por el Norte de Chile. En el espejo del desierto, salitreras y oasis. Viaje, 383, 16-17.

. (1966). Orígenes históricos de Antofagasta. I.M.A. Santiago, Chile: Editorial Universitaria.

Casaly, L. (1961). Prólogo a Grupo de Letras. Y al NORTE...la POESIA (pp.7-9). Antofagasta: Talleres Gráficos del Liceo de Hombres. 
Claps, G. (1996). Origen y papel de la Universidad Católica del Norte. En J. A. González (Coordinador), La Universidad Católica del Norte y el desarrollo regional nortino 19561996 (pp. 9-81). Antofagasta: Ediciones Universidad Católica del Norte.

De la Puente. J. (2010). La ensayística de Martín Cerda. Universum, 2 (25), 29-39.

Devés, E. (2003). El pensamiento latinoamericano en el siglo XX. Desde la Cepal al neoliberalismo (1950-1990). Tomo III. Buenos Aires: Editorial Biblos-Centro de Investigaciones Diego Barros Arana.

Díaz-Muñoz, C. (1962). Nuevas Escribanías. Santiago, Chile: Imprenta Maisel.

Gazmuri, C. (2009). La Historiografía Chilena (1920-1970). Volumen II. Santiago de Chile: Centro de Investigaciones Diego Barros Arana-Editorial Taurus.

González, J.A. (1983). Breve bosquejo de la pampa y del hombre nortino en la literatura chilena. Anales de Literatura Hispanoamericana, 12, 81-97.

. (2002). La pampa salitrera en la región de Antofagasta. La vida cotidiana durante los sistemas Shanks y Guggenheim en el desierto de Atacama. Antofagasta: Corporación Pro Antofagasta.

- (2007). La imagen de Chile en la obra inédita y desconocida de Andrés Sabella (1912-1989). Historia, 1 (40), 35-68.

- (2009). Imaginarios contrapuestos: El desierto de Atacama percibido desde la región y mirado desde la nación. Revista de Dialectología y Tradiciones Populares. Antropología. Etnografía, Folklore, LXIV (2), 91-116.

González, L. (1957). El Norte Grande. Su medio y su gente. En Nicomedes Guzmán [Dirección, prólogo y notas], Autorretrato de Chile (pp. 41-49). Santiago, Chile: Editorial ZigZag. 
Guerra, L. (1987). Texto e ideología en la narrativa chilena. Indiana, EE.UU: University of Indiana.

Guzmán, N. (1957). Conversación sobre este "Autorretrato de Chile". En Nicomedes Guzmán [Dirección, prólogo y notas]. Autorretrato de Chile (pp.13-19). Santiago, Chile: Editorial Zig-Zag.

Heidegger, M. (1997). Construir Habitar Pensar. En M. Heidegger [Autor]. Filosofía, Ciencia y Técnica (pp. 199-219). Santiago, Chile: Editorial Universitaria.

Latcham, R.A. (18 de junio de 1964). 25 años de Literatura Chilena. Vea. Número Especial. Recuperado de: <www.angelfire. $\mathrm{com} / \mathrm{nj} /$ poesia/25year.html>

Madrigal, L. (1976). La novela de la "Generación del 38". Hispamérica, $14,27-43$.

Moll, María Elena. (2000). El ensayo como estructura lingüística y construcción del sentido. Onomazein, (5), 289-294.

Ortega y Gasset, J. (1939). Ensimismamiento y alteración. Meditación de la técnica. Buenos Aires: Espasa-Calpe.

Pinedo. J. (1987-1988). La ensayística y el problema de la identidad 19601988. En José Luis Gómez Martínez y Francisco Javier Pinedo (Editores), Los ensayistas. Chile. 19681988, (pp. 231-264). Georgia, EE.UU: The University of Georgia.

Reyes, S. (1969). Andanzas por el desierto de Atacama. Santiago, Chile: Editorial Zig-Zag.

Rivano, J. (1964). La América ahistórica y sin mundo del humanista Ernesto Grassi. Mapocho, 2 (1), 114-131.

Sabella, A. (1957). Extensión Cultural. En VV.AA., Seminario de Problemas Regionales de Antofagasta organizado por la Universidad de Chile, (pp. 324-332). Santiago, Chile: Ediciones del Departamento de Extensión Cultural. . (1986). Semblanza del norte chileno.Seguida de once romances de feria del Guitarron de Taguada (2da. Edición). Santiago, Chile: Editorial Alfa S.A. 
Said. E. (2004). El Mundo, el texto y el crítico. Madrid: Editorial Debate.

San Román, F.J. (1896). Desiertos y Cordilleras de Atacama. Itinerario de las exploraciones. Tomo Primero. Santiago, Chile: Imprenta Nacional.

Sánchez, C. (1992). Una disciplina de la Distancia. Institucionalización universitaria de los estudios filosóficos en Chile. Santiago, Chile.: Centro de Estudios de la Realidad Contemporánea, Universidad Academia de Humanismo Cristiano.

Sander, C. (1963). Entre la pampa y el mar. Antofagasta: Ediciones de la Universidad de Chile.

Silva C, R. (1962). El Ensayo en Chile. Journal of Inter-American Studies, 4 (4), 441-461.

Taberna, F. (1971). Algo sobre las comunidades tradicionales andinas de Tarapacá. En Bernardo Guerrero (Editor), Homenaje a Freddy Taberna G. Escritos sobre la sociedad aymara del Norte Grande de Chile (pp.17-39). Iquique: Centro de Investigación de la Realidad del Norte.

Vidal, S. (1977). La filosofía en Chile. Cuadernos de Filosofía, 6, 19-44.

Weinberg, L. (2007). El ensayo latinoamericano entre la forma de la moral y la moral de la forma. Cuadernos del CILHA, 9, 110130.

Urzúa, L. (1969). Arica, puerta nueva. Historia y Folklore. (3ra. Edición). Santiago, Chile: Editorial Andrés Bello.

Wormald, A. (1968). Frontera Norte. (2da. Edición). Santiago, Chile: Editorial Orbe. 